\section{Prevalence and Associated Factors for the Development of Anterior 0pen Bite and Posterior Crossbite in the Primary Dentition}

Raulison Vieira de Sousa ${ }^{1}$, Gabriella Lima Arrais Ribeiro ${ }^{1}$, Ramon Targino Firmino ${ }^{1}$, Carolina Castro Martins ${ }^{2}$, Ana Flávia Granville-Garcia ${ }^{1}$, Saul Martins Paiva ${ }^{2}$

\author{
'Department of Dentistry, UEPB \\ - State University of Paraíba, \\ Campina Grande, PB, Brazil \\ ${ }^{2}$ Department of Dentistry and \\ Pediatric Dentistry, UFMG - \\ Federal University of Minas Gerais, \\ Belo Horizonte, MG, Brazil
}

Correspondence: Prof. Dr. Saul Martins Paiva, Avenida Bandeirantes, 2275/500, 30210-420 Belo Horizonte, MG, Brasil. Tel: +55-31-3409-2470. e-mail: smpaiva@uol.com.br

\begin{abstract}
The aim of the study was to verify the prevalence of anterior open bite (AOB) and posterior cross-bite (PC) in the primary dentition and the association with sociodemographic factors, presence and duration of nutritive and non-nutritive habits. A cross-sectional study was carried out with 732 preschoolers in Campina Grande, PB, Brazil. Clinical exams were performed by three calibrated examiners (Kappa: 0.85-0.90). A questionnaire addressing sociodemographic data as well as nutritive and non-nutritive sucking habits was administered to parents/caregivers. Data analysis involved descriptive statistics and Poisson regression analysis $(\alpha=5 \%)$. The prevalence of AOB and PC was $21.0 \%$ and $11.6 \%$, respectively. $A O B$ was significantly associated with the three-year-old age group (PR: 1.37; 95\% Cl: 1.24-1.52), enrollment in public school (PR: $1.09 ; 95 \% \mathrm{Cl}: 1.01-1.17)$ and duration of pacifier sucking $\geq 36$ months (PR: $1.41 ; 95 \% \mathrm{Cl}: 1.30-1.53$ ). PC was associated with pacifier use (PR: $1.11 ; 95 \% \mathrm{Cl}: 1.05-1.17)$ and duration of breastfeeding $<12$ months (PR: $1.05 ; 95 \% \mathrm{Cl}: 1.00-1.10)$. Socioeconomic factors appear not to be related to AOB or PC in the primary dentition, except type of preschool. Breastfeeding should be encouraged for longer periods and the use of pacifier beyond 3 years of age represents a predisposing factor for both types of malocclusion, especially $\mathrm{AOB}$.
\end{abstract}

\section{Introduction}

Malocclusions in the primary dentition may be considered a public health problem due to the high rates of prevalence and treatment needs as well as the social impact such conditions may cause (1). Knowledge of malocclusion etiology is essential for the success of orthodontic treatment, since eliminating the cause is a prerequisite for correction of the problem. In view of the increasing interest in early diagnosis and corresponding emphasis on preventive procedures, further information on factors associated with malocclusion is needed (2).

Anterior open bite (AOB) and posterior crossbite (PC) are the most prevalent forms of malocclusion in the primary dentition $(3,4)$. AOB develops at an early age, but may selfcorrect spontaneously in subsequent years (5). In contrast, $P C$ is believed to be transferred from the primary to the permanent dentition (2). Malocclusion is the result of the interaction of genetic and environmental factors (3). Nonnutritive sucking habits (NNSH) are the main etiological factors associated with AOB (6). Heredity, mouth-breathing pattern, nutritive sucking habits (NSH) and hypertrophy of the adenoids and tonsils are the main etiological factors associated with PC $(7,8)$. While a number of studies have associated NNSH and other environmental factors with malocclusion $(3,6,7,9)$, few investigations have sought to establish associations between sociodemographic factors and malocclusion $(2,3)$, especially in children less than 5 years old. Moreover, most studies analyze predisposing factors separately, without measuring concurrent impact or assessing potential interactions (3). Clinical interest in the etiology and early diagnosis of malocclusion justifies epidemiological investigations focused on the main types of malocclusion found in preschool children (2).

The aim of the study was to verify the prevalence of anterior open bite (AOB) and posterior cross-bite (PC) in the primary dentition and the association with sociodemographic factors, presence and duration of nutritive and non-nutritive habits.

\section{Material and Methods Sample Characteristics}

A population-based cross-sectional study was carried out involving a random sample of 732 male and female children aged 3 to 5 years enrolled at private and public preschools in the city of Campina Grande, PB, Brazil. The participants were selected from a total population of 12,705 children in this age group, corresponding to $6.6 \%$ of the population (10).

A two-phase sampling method was used to ensure representativeness. Preschools were randomly selected 
from each health district in the first phase and children were randomly selected from each preschool in the second phase. Eighteen of the 127 public preschools and 15 of the 122 private preschools were randomly selected by lots. The sample size was calculated with a $4 \%$ margin of error, a 95\% confidence level and a 50.0\% prevalence rate of malocclusion. A correction factor of 1.2 was applied to compensate for the design effect (11). The minimum sample size was estimated at 720 schoolchildren, to which 20\% was added to compensate for possible losses, resulting in a total sample of 864 schoolchildren.

This study received approval from the Human Research Ethics Committee of the State University of Paraiba, Brazil (00460133000-11) in compliance with the Brazilian National Health Council Resolution 196/96. All parents/ guardians received information regarding the objectives of the study and signed a statement of informed consent.

\section{Eligibility Criteria}

Inclusion criteria: age 3 to 5 years; exclusively in the primary dentition phase; agreement to participate in the clinical exam. Exclusion criteria: presence of at least one permanent tooth; loss of mesiodistal diameter due to caries; previous orthodontic treatment; refusal to participate in the clinical exam.

\section{Training and Calibration Exercise}

The theoretical phase involved a discussion of diagnostic criteria for malocclusion and an analysis of photographs. A specialist in orthodontic dentistry was the gold standard in the theoretical framework, instructing three dentists on how to perform the exam. The second phase was a clinical examination. Each dentist examined 50 children and inter-examiner agreement was tested by comparing each examiner with the gold standard. Thirty children were reexamined after a seven-day interval for the determination of intra-examiner agreement. Data analysis involved the calculation of the Kappa coefficient ( $K=0.85$ to 0.90 for both inter-examiner and intra-examiner agreement).

\section{Pilot Study}

A pilot study was conducted to test the methodology and understanding of the questionnaire with a sample of 40 children that were not included in the main sample. The results revealed no misunderstandings regarding the questionnaire or any need for changes in the method.

\section{Non-clinical Data Collection}

Parents/caregivers answered a questionnaire addressing sociodemographic data and both the NSH and NNSH of the child. Household income was categorized based on the monthly minimum wage in Brazil, which was equal to
US\$312.50 at the time of the study.

\section{Clinical Data Collection}

Clinical examination was performed after the return of the questionnaires by three dentists blinded to the answers of the questionnaires. The exams were performed at the preschool facilities in the knee-to-knee position with a portable lamp attached to the examiner's head (Petzl ${ }^{\circledR}$, Clearfield, PA, USA). Individual cross-infection protection equipment was used. Packaged and sterilized disposable dental mirrors (PRISMA ${ }^{\oplus}$, São Paulo, SP, Brazil), WHO probes (Trinity ${ }^{\oplus}$, Campo Mourão, PR, Brazil) and dental gauze (to dry the teeth) were used for the examination. Aspects of $A O B$ and $P C$ were recorded. Radiography was not used for the diagnosis $(12,13)$. AOB was characterized as the absence of vertical overlap of the mandibular incisors (cases of edge-to-edge bite were considered normal) (13). PC was recorded when the maxillary primary molars occluded in lingual relationship to the mandibular molars in centric occlusion (12).

\section{Statistical Analysis}

Descriptive statistics were conducted to describe the characteristics of the sample and prevalence of malocclusion. Two bivariate Poisson regression models were constructed - one for $\mathrm{AOB}$ and another for PC. The independent variables were sociodemographic indicators, NSH and NNSH $(p<0.05)$. Multivariate Poisson analysis with the forward stepwise procedure was then conducted for $A O B$ and $P C$. Independent variables with a $p$ value of $<0.20$ in the bivariate analysis were incorporated into the multivariate model. Data organization and statistical analysis were performed using the Statistical Package for Social Sciences (SPSS for Windows 18.0, SPSS Inc, Chicago, IL, USA).

\section{Results}

A total of 732 pairs of children and parents/guardians participated in the present study, corresponding to $84.72 \%$ of the total based on the sample calculation $(n=864)$. The loss of 132 children (15.28\%) was due to absence from preschool more than three times on the days scheduled for the clinical exams $(n=76)$ and lack of cooperation during the exam $(n=56)$. Table 1 displays the characterization of the sample. The prevalence of $A O B$ and PC was $21 \%$ and $11.6 \%$, respectively. A total of $94.1 \%$ of the cases of PC were unilateral. In the final logistic model, age was associated with $A O B$, with a greater prevalence among 3-year-olds (PR: $1.37 ; 95 \% \mathrm{Cl}: 1.24$ to 1.52). Moreover, the prevalence of this malocclusion was greater among children attending public schools (PR: 1.09; 95\% Cl: 1.01 to 1.17) (Table 2). Duration of pacifier sucking was also associated with $A O B$, 
as prevalence of this malocclusion was greater among children who used a pacifier for more than 36 months (PR: $1.41 ; 95 \% \mathrm{Cl}: 1.30$ to 1.53$)$. Prevalence of PC was greater among children who used pacifiers. This variable remained significant in the final model (PR: $1.11 ; 95 \% \mathrm{Cl}: 1.05$ to 1.17). Having been breastfed for less than 12 months was also associated with a greater prevalence rate of PC (PR: 1.05; 95\% Cl: 1.00 to 1.10) (Table 3).

\section{Discussion}

In the present study, prevalence of AOB was $21 \%$ and prevalence of PC was $11.6 \%$. Studies report prevalence rates ranging from $6.0 \%$ to $46.2 \%$ for $\mathrm{AOB}(3,13,14)$ and $10.4 \%$ to $13.1 \%$ for $\mathrm{PC}(2,7,14)$. The divergence likely occurs due to different cultural and economic standards across countries, which may influence the habits and behavior of the population $(2,6)$. PC is a type of malocclusion that develops early and rarely self-corrects. Thus, the primary dentition is the ideal phase for preventive or interceptive measures (15).

Most of the sociodemographic variables were not associated with either type of malocclusion. The fact that gender was not associated with $\mathrm{AOB}$ or PC agrees with findings reported in previous studies $(3,16,17)$. Among the employed socioeconomic indicators, type of school was the only factor significantly associated with $\mathrm{AOB}$ and was

Table 1. Sociodemographic characteristics of the sample

\begin{tabular}{llc}
\hline Variable & $\mathrm{n}$ & $\%$ \\
\hline Gender & & \\
Male & 384 & 52.5 \\
Female & 348 & 47.5 \\
Age (years) & & \\
3 & 230 & 31.4 \\
4 & 341 & 46.6 \\
5 & 161 & 22.0 \\
Mother's schooling & & \\
$\leq 8$ years of study & 321 & 43.9 \\
$>8$ years of study & 411 & 56.1 \\
Monthly household income & & \\
$\leq 3$ times the Brazilian minimum wage & 587 & 80.2 \\
$>3$ times the Brazilian minimum wage & 145 & 19.8 \\
Type of school & & \\
Private & 353 & 48.2 \\
Public & 51.8 \\
Total & & \\
\hline
\end{tabular}

not associated with PC. Brazil is currently experiencing an increase in per capita income (10) and type of school may no longer be an effective socioeconomic indicator. Thus, the greater prevalence of $\mathrm{AOB}$ among children attending public preschools may have been due to the fact that children up to four years of age spend most of the day in public preschools and absence of the mother may facilitate the adoption of NNSH (2) or caregivers may be more permissive with regard to such habits. Indeed, the findings of the present investigation and previous studies indicate that the development of these types of malocclusion is not dependent on socioeconomic factors $(2,3,17)$.

Age was associated with $A O B$. Reduction in the prevalence of this malocclusion with the advancing age indicates self-correction, which is in agreement with findings described in previous studies $(13,17)$. The cause of this decline may be due to changes in growth, dental alterations and a decrease in the prevalence of harmful oral habits (17). There is a tendency toward a decrease in the prevalence of NNSH with the increased age (6). Moreover, there is evidence that longer NNSH period increases the risk of malocclusion in the primary dentition (18). Indeed, decrease in the prevalence of NNSH as the children grow up may explain why it is possible for AOB to correct itself.

In the analysis of sucking habits, only the duration of pacifier use remained significantly associated with malocclusion in the final model. The prevalence of AOB was greater among children who used pacifiers for more than 36 months. Other studies have also found an association between pacifier sucking for a long period and AOB $(3,19)$. This corroborates with the aforementioned association between age and $\mathrm{AOB}$ and suggests that this malocclusion may self-correct if NNSH are abandoned by the age of 3 years. Pacifier sucking was associated with PC regardless of the duration, which is in agreement with findings of previous studies $(2,3,8,19)$. A longitudinal study found that NNSH for more than 48 months was a risk factor for both $A O B$ and $P C$ (18). In the present study, however, duration of pacifier use was not associated with PC. Age was also not associated with this malocclusion. Moreover, PC does not self-correct and may be transferred to the permanent dentition (13).

The high prevalence of PC in young dummy suckers is likely due to the increased activity of the cheeks combined with reduced lingual support for the primary maxillary molars and canines as the tongue is forced backward and downward by the dummy teat. Possibly the low position of the tongue widens the lower arch, thereby contributing to the development of PC in the primary dentition (20). It seems that pacifier sucking is more associated with PC and finger sucking is more associated with overjet (19). Moreover, prolonged pacifier sucking may have more 
Table 2. Bivariate and multivariate Poisson regression models for anterior open bite (AOB) and independent variables among children aged 3 to 5 years

\begin{tabular}{|c|c|c|c|c|c|c|}
\hline \multirow{3}{*}{ Variable } & \multicolumn{2}{|c|}{ AOB } & \multirow{2}{*}{\multicolumn{2}{|c|}{$\begin{array}{c}\text { Bivariate } \\
\text { Unadjusted } \mathrm{PR}^{*}\end{array}$}} & \multirow{2}{*}{\multicolumn{2}{|c|}{$\begin{array}{c}\text { Multivariate } \\
\text { Adjusted PR *** }\end{array}$}} \\
\hline & \multirow{2}{*}{$\frac{\text { Present }}{n(\%)}$} & \multirow{2}{*}{$\frac{\text { Absent }}{n(\%)}$} & & & & \\
\hline & & & $p$-value & $(95 \% \mathrm{Cl})$ & p-value & $(95 \% \mathrm{Cl})$ \\
\hline \multicolumn{7}{|l|}{ Gender } \\
\hline Male & $76(21.8)$ & $272(78.2)$ & 0.61 & $1.01(0.96-1.06)$ & - & - \\
\hline Female & $78(20.3)$ & 306(79.7) & & 1.00 & - & - \\
\hline \multicolumn{7}{|l|}{ Age (years) } \\
\hline 3 & $62(27.0)$ & $168(73.0)$ & $<0.001$ & $1.14(1.07-1.22)$ & $<0.001$ & $1.37(1.24-1.52)$ \\
\hline 4 & $75(22.0)$ & 266(78.0) & 0.001 & $1.10(1.04-1.16)$ & $<0.001$ & $1.17(1.08-1.28)$ \\
\hline 5 & $17(10.6)$ & $144(89.4)$ & & 1.00 & & 1.00 \\
\hline \multicolumn{7}{|l|}{ Mother's schooling } \\
\hline$\leq 8$ years of study & $91(28.3)$ & $230(71.7)$ & $<0.001$ & $1.11(1.06-1.16)$ & - & - \\
\hline$>8$ years of study & $63(15.3)$ & $348(84.7)$ & & 1.00 & - & - \\
\hline \multicolumn{7}{|l|}{ Monthly household income } \\
\hline$\leq 3$ times minimum wage & $141(24.0)$ & $446(76.0)$ & $<0.001$ & $1.13(1.08-1.19)$ & - & - \\
\hline$>3$ times minimum wage & 13(9.0) & 132(91.0) & & 1.00 & - & - \\
\hline \multicolumn{7}{|l|}{ Type of school } \\
\hline Private & $104(27.4)$ & $275(72.6)$ & \multirow{2}{*}{0.001} & $1.11(1.06-1.17)$ & 0.02 & $1.09(1.01-1.17)$ \\
\hline Public & $50(14.2)$ & $303(85.8)$ & & 1.00 & & 1.00 \\
\hline \multicolumn{7}{|l|}{ Pacifier sucking } \\
\hline Yes & $134(38.6)$ & $213(61.4)$ & $<0.001$ & $1.31(1.26-1.37)$ & - & - \\
\hline No & $20(5.2)$ & $365(94.8)$ & & 1.00 & - & - \\
\hline \multicolumn{7}{|l|}{ Duration of pacifier sucking } \\
\hline$<36$ months & 43(19.5) & $177(80.5)$ & & 1.00 & & 1.00 \\
\hline$\geq 36$ months & $75(73.5)$ & $27(26.5)$ & $<0.001$ & $1.45(1.35-1.55)$ & $<0.001$ & $1.41(1.30-1.53)$ \\
\hline \multicolumn{7}{|l|}{ Finger sucking } \\
\hline Yes & $21(27.3)$ & $56(72.7)$ & 0.18 & $1.05(0.97-1.14)$ & - & - \\
\hline No & 133(20.3) & $522(79.7)$ & & 1.00 & - & - \\
\hline \multicolumn{7}{|l|}{ Duration of finger sucking } \\
\hline$<36$ months & $8(22.9)$ & $27(77.1)$ & & 1.00 & - & - \\
\hline$\geq 36$ months & $7(25.0)$ & $21(75.0)$ & 0.84 & $1.01(0.85-1.20)$ & - & - \\
\hline \multicolumn{7}{|l|}{ Bottle feeding } \\
\hline Yes & $128(21.6)$ & $464(78.4)$ & 0.41 & $1.02(0.96-1.09)$ & - & - \\
\hline No & $26(18.6)$ & $114(81.4)$ & & 1.00 & - & - \\
\hline \multicolumn{7}{|l|}{ Duration of bottle feeding } \\
\hline$<36$ months & $55(18.8)$ & $237(81.2)$ & & 1.00 & - & - \\
\hline$\geq 36$ months & $63(25.5)$ & $184(74.5)$ & 0.06 & $1.05(0.99-1.11)$ & - & - \\
\hline \multicolumn{7}{|l|}{ Breastfeeding } \\
\hline Yes & $131(20.1)$ & $521(79.9)$ & & 1.00 & - & - \\
\hline No & $23(28.8)$ & $57(71.3)$ & 0.09 & $1.07(0.98-1.16)$ & - & - \\
\hline \multicolumn{7}{|l|}{ Duration of breastfeeding } \\
\hline$<12$ months & $103(27.5)$ & $271(72.5)$ & $<0.001$ & $1.17(1.11-1.23)$ & - & - \\
\hline$\geq 12$ month & 21(8.6) & $222(91.4)$ & & 1.00 & - & - \\
\hline \multicolumn{7}{|l|}{ Type of feeding } \\
\hline Exclusive breastfeeding & $67(20.7)$ & 256(79.3) & 0.72 & $1.00(0.95-1.06)$ & - & - \\
\hline Mixed feeding & 65(19.6) & $266(80.4)$ & & 1.00 & - & - \\
\hline
\end{tabular}

*Poisson regression not adjusted for independent variables and anterior open bite. **Variables incorporated into multivariate model (p<0.20): age, mother's schooling, income, type of school, pacifier sucking, duration of pacifier sucking, duration of bottle feeding, breastfeeding and duration of breastfeeding. ${ }^{* * *}$ Poisson regression adjusted for independent variables and anterior open bite 
Table 3. Bivariate and multivariate Poisson regression models for posterior crossbite (PC) and independent variables among children aged 3 to 5 years

\begin{tabular}{|c|c|c|c|c|c|c|}
\hline \multirow{3}{*}{ Variable } & \multicolumn{2}{|c|}{ PC } & \multirow{2}{*}{\multicolumn{2}{|c|}{$\begin{array}{c}\text { Bivariate } \\
\text { Unadjusted } \mathrm{PR}^{*}\end{array}$}} & \multirow{2}{*}{\multicolumn{2}{|c|}{$\begin{array}{c}\text { Multivariate } \\
\text { Adjusted PR **** }\end{array}$}} \\
\hline & \multirow{2}{*}{$\begin{array}{c}\text { Present } \\
\mathrm{n}(\%)\end{array}$} & \multirow{2}{*}{$\frac{\text { Absent }}{\mathrm{n}(\%)}$} & & & & \\
\hline & & & $\mathrm{p}$-value & $(95 \% \mathrm{Cl})$ & p-value & $(95 \% \mathrm{Cl})$ \\
\hline \multicolumn{7}{|l|}{ Gender } \\
\hline Male & $50(14.4)$ & 298(85.6) & 0.02 & $1.04(1.00-1.09)$ & - & - \\
\hline Female & $35(9.1)$ & 349(90.9) & & 1.00 & - & - \\
\hline \multicolumn{7}{|l|}{ Age (years) } \\
\hline 3 & $26(11.3)$ & 204(88.7) & 0.52 & $1.01(0.96-1.07)$ & - & - \\
\hline 4 & $44(12.9)$ & $297(87.1)$ & 0.22 & $1.03(0.98-1.08)$ & - & - \\
\hline 5 & 15(9.3) & 146(90.7) & & 1.00 & & - \\
\hline \multicolumn{7}{|l|}{ Mother's schooling } \\
\hline$\leq 8$ years of study & $40(12.5)$ & $281(87.5)$ & 0.52 & $1.01(0.97-1.05)$ & - & - \\
\hline$>8$ years of study & $45(10.9)$ & $366(89.1)$ & & 1.00 & - & - \\
\hline \multicolumn{7}{|l|}{ Monthly household income } \\
\hline$\leq 3$ times minimum wage & $67(11.4)$ & $520(88.6)$ & & 1.00 & - & - \\
\hline$>3$ times minimum wage & $18(12.4)$ & $127(87.6)$ & 0.74 & $1.00(0.95-1.06)$ & - & - \\
\hline \multicolumn{7}{|l|}{ Type of school } \\
\hline Private & $44(11.6)$ & $335(88.4)$ & \multirow{2}{*}{0.99} & $1.00(0.95-1.04)$ & - & - \\
\hline Public & $41(11.6)$ & $312(88.4)$ & & 1.00 & - & - \\
\hline \multicolumn{7}{|l|}{ Pacifier sucking } \\
\hline Yes & $63(18.2)$ & 284(81.8) & $<0.001$ & $1.11(1.07-1.16)$ & $<0.001$ & $1.11(1.05-1.17)$ \\
\hline No & $22(5.7)$ & $363(94.3)$ & & 1.00 & & 1.00 \\
\hline \multicolumn{7}{|l|}{ Duration of pacifier sucking } \\
\hline$<36$ months & $34(15.5)$ & $186(84.5)$ & & 1.00 & - & - \\
\hline$\geq 36$ months & $26(25.5)$ & $76(74.5)$ & 0.03 & $1.08(1.00-1.17)$ & - & - \\
\hline \multicolumn{7}{|l|}{ Finger sucking } \\
\hline Yes & $10(13.0)$ & $67(87.0)$ & 0.70 & $1.01(0.94-1.08)$ & - & - \\
\hline No & $75(11.5)$ & $580(88.5)$ & & 1.00 & - & - \\
\hline \multicolumn{7}{|l|}{ Duration of finger sucking } \\
\hline$<36$ months & $5(14.3)$ & $30(85.7)$ & 0.66 & $1.03(0.89-1.19)$ & - & - \\
\hline$\geq 36$ months & $3(10.7)$ & 25(89.3) & & 1.00 & - & - \\
\hline \multicolumn{7}{|l|}{ Bottle feeding } \\
\hline Yes & $78(13.2)$ & $514(86.8)$ & $<0.001$ & $1.07(1.03-1.12)$ & - & - \\
\hline No & $7(5.0)$ & 133(95.0) & & 1.00 & - & - \\
\hline \multicolumn{7}{|l|}{ Duration of bottle feeding } \\
\hline$<36$ months & $39(13.4)$ & 253(86.6) & & 1.00 & - & - \\
\hline$\geq 36$ months & $33(13.4)$ & $214(86.6)$ & 0.99 & $1.00(0.95-1.05)$ & - & - \\
\hline \multicolumn{7}{|l|}{ Breastfeeding } \\
\hline Yes & $75(11.5)$ & $577(88.5)$ & & 1.00 & - & - \\
\hline No & $10(12.5)$ & $70(87.5)$ & 0.79 & $1.00(0.94-1.08)$ & - & - \\
\hline \multicolumn{7}{|l|}{ Duration of breastfeeding } \\
\hline$<12$ months & $57(15.2)$ & $317(84.8)$ & $<0.001$ & $1.09(1.04-1.14)$ & 0.03 & $1.05(1.00-1.10)$ \\
\hline$\geq 12$ month & $13(5.3)$ & $230(94.7)$ & & 1.00 & & 1.00 \\
\hline \multicolumn{7}{|l|}{ Type of feeding } \\
\hline Exclusive breastfeeding & $32(9.9)$ & $291(90.1)$ & & 1.00 & - & - \\
\hline Mixed feeding & $43(13.0)$ & 288(87.0) & 0.21 & $1.02(0.98-1.07)$ & - & - \\
\hline
\end{tabular}

*Poisson regression not adjusted for independent variables and posterior crossbite. **Variables incorporated into multivariate model ( $p<0.20):$ gender, pacifier sucking, duration of pacifier sucking, bottle feeding and duration of breastfeeding. ${ }^{* * *}$ Poisson regression adjusted for independent variables and posterior crossbite 
harmful effects on the bite than the finger sucking habit (8). Indeed, no association was found between finger sucking and $\mathrm{PC}$ in the present investigation, which is in agreement with findings of previous studies $(2,9)$.

Breastfeeding for less than 12 months was associated with PC. A number of studies report that a shorter period of breastfeeding increases the risk of the development of PC due to the greater susceptibility to the adoption of NNSH as a way to fulfill natural sucking needs $(3,15,21,22)$. On the other hand, association between pacifier sucking and early weaning remains unclear. While a number of studies report the influence of pacifier sucking on early weaning $(6,21)$, a recent literature review conducted with two trials found no effect of pacifier use on the duration of breastfeeding in children aged 3 and 4 months (23). Breastfeeding should be encouraged for as long as possible. Exclusive breastfeeding until 6 months of age is recommended by the World Health Organization to minimize the occurrence of gastrointestinal infection and weight deficit $(24,25)$, and may be a protective factor against malocclusion, as found in the present study. In general, pacifier sucking should be avoided. If this is not possible, the practice should be discontinued by the age of 36 months to avoid the development of malocclusions.

The present study has limitations that should be addressed. Information bias may have occurred with regard to income and memory bias may have occurred regarding the duration of sucking habits. However, this investigation was a randomized, population-based study and the results may be extrapolated to the population. AOB and PC may require professional assistance during the primary dentition stage in the form of counseling on the importance of discontinuing NNSH, which may or may not be combined with interceptive orthodontic treatment. Some form of intervention is often required to prevent dentoskeletal alterations and eliminate perpetuating factors that affect swallowing and speech, such as interposition of the tongue between the incisors (16).

In view of these results, it was concluded that except for the type of school, no socioeconomic factors were associated with malocclusion in the primary dentition. Breastfeeding for a prolonged time seems to be a protective factor against $\mathrm{PC}$ and pacifier sucking is a risk factor for the development of both $\mathrm{AOB}$ and $\mathrm{PC}$, especially the former when this practice persists for over than 3 years of age.

\section{Resumo}

0 objetivo do estudo foi verificar a prevalência de mordida aberta anterior (MAA) e mordida cruzada posterior (MCP) na dentição decidua e a associação com fatores sociodemográficos, presença e duração de hábitos nutritivos e não nutritivos. Um estudo transversal foi conduzido com 732 pré-escolares de Campina Grande, Brasil. Os exames clínicos foram realizados por três examinadores calibrados (Kappa: 0,85-0,90). Um questionário abordando dados socioeconômicos, bem como hábitos de sucção nutritiva e não-nutritiva foi aplicado aos pais/responsáveis. A analise dos dados envolveu estatística descritiva e analise de regressão de Poisson $(\alpha=5 \%)$. A prevalência de MAA e MCP foi $21,0 \%$ e $11,6 \%$, respectivamente. A MAA foi associada ao grupo de três anos de idade (RP: 1,37; 95\%lC: 1,24-1,52), pertencer à escola publica (RP: 1,09; 95\% IC: $1,01-1,17)$ e duração do habito de sucção de chupeta $\geq 36$ meses (RP: $1,41 ; 95 \%$ IC: $1,30-1,53)$. A MCP foi associada ao uso de chupeta (RP: 1,11 ; 95\%lC: 1,05-1,17) e tempo de amamentação < 12 meses (RP: 1,$05 ; 95 \%$ IC: 1,00-1,10). Os fatores socioeconômicos aparentam não estar relacionados à MAA ou MCP na dentição decídua, exceto pelo tipo de pré-escola. A amamentação natural deve ser incentivada por maiores periodos de tempo e o uso de chupeta além dos três anos de idade representa um fator de predisposição para ambas as má-oclusões, especialmente a MAA.

\section{References}

1. Peres KG, Traebert ES, Marcenes W. Differences between normative criteria and self-perception in the assessment of malocclusion. Rev Saude Publica 2002;36:230-236.

2. Macena $M C$, Katz CR, Rosenblatt A. Prevalence of a posterior crossbite and sucking habits in Brazilian children aged 18-59 months. Eur J Orthod 2009;31:357-361.

3. Peres KG, Barros AJ, Peres MA, Victora CG. Effects of breastfeeding and sucking habits on malocclusion in a birth cohort study. Rev Saude Publica 2007;41:343-350.

4. Melink S, Vagner MV, Hocevar-Boltezar I, Ovsenik M. Posterior crossbite in the deciduous dentition period, its relation with sucking habits, irregular orofacial functions, and otolaryngological findings. Am J Orthod Dentofacial Orthop 2010;138:32-40.

5. Berneburg M, Zeyher C, Merkle T, Möller M, Schaupp E, Göz G. Orthodontic findings in 4- to 6-year-old kindergarten children from southwest Germany. J Orofac Orthop 2010;71:174-186.

6. Heimer MV, Katz CR, Rosenblatt A. Non-nutritive sucking habits, dental malocclusions, and facial morphology in Brazilian children: a longitudinal study. Eur J Orthod 2008;30:580-585.

7. Katz CR, Rosenblatt A, Gondim PP. Nonnutritive sucking habits in Brazilian children: effects on deciduous dentition and relationship with facial morphology. Am J Orthod Dentofacial Orthop 2004;126:53-57.

8. Scavone-Júnior H, Ferreira RI, Mendes TE, Ferreira FV. Prevalence of posterior crossbite among pacifier users: a study in the deciduous dentition. Braz Oral Res 2007;21:153-158.

9. Corrêa-Faria $P$, Ramos-Jorge $M L$, Martins-Júnior PA, Vieira-Andrade RG, Marques LS. Malocclusion in preschool children: prevalence and determinant factors. Eur Arch Paediatr Dent 2014; 15:89-96.

10. IBGE - Instituto Brasileiro de Geografia e Estatística. Census results 2010. [Latest access in August 2014]. Available from http://www. censo2010.ibge.gov.br/

11. David J, Astrom AN, Wang NJ. Factors associated with traumatic dental injuries among 12-year-old schoolchildren in South India. Dent Traumatol 2009;25:500-505.

12. Foster TD, Hamilton MC. Occlusion in the primary dentition: study of children at 2 and one-half to 3 years of age. Br Dent J 1969;126:76-79.

13. Grabowski R, Stahl F, Gaebel M, Kundt G. Relationship between occlusal findings and orofacialmyofunctional status in primary and mixed dentition. Part I: Prevalence of malocclusions. J Orofac Orthop 2007;68:26-37.

14. Carvalho AC, Paiva SM, Scarpelli AC, Viegas CM, Ferreira FM, Pordeus IA. Prevalence of malocclusion in primary dentition in a populationbased sample of Brazilian preschool children. Eur J Paediatr Dent 2011;12:107-111.

15. Kobayashi HM, Scavone H Jr, Ferreira RI, Garib DG. Relationship between breastfeeding duration and prevalence of posterior crossbite in the deciduous dentition. Am J Orthod Dentofacial Orthop 2010;137:54-58.

16. Frazão $P$, Narvai PC, Latorre MR, Castellanos RA. Are severe occlusal problems more frequent in permanent than deciduous dentition? Rev Saude Publica 2004;38:247-254.

17. Vasconcelos FM, Massoni AC, Heimer MV, Ferreira AM, Katz CR, Rosenblatt $A$. Non-nutritive sucking habits, anterior open bite and 
associated factors in Brazilian children aged 30-59 months. Braz Dent J $2011 ; 22: 140-145$

18. Warren JJ, Bishara SE, Steinbock KL, Yonezu T, Nowak AJ. Effects of oral habits' duration on dental characteristics in the primary dentition. J Am Dent Assoc 2001;132:1685-1693.

19. Bishara SE, Warren JJ, Broffitt B, Levy SM. Changes in the prevalence of nonnutritive sucking patterns in the first 8 years of life. Am J Orthod Dentofacial Orthop 2006;130:31-36.

20. Larsson E. The effect of dummy-sucking on the occlusion: a review. Eur J Orthod 1986;8:127-130.

21. Kramer MS, Barr RG, Dagenais S, Yang H, Jones $P$, Ciofani L et al. Pacifier use, early weaning, and cry/fuss behavior: a randomized controlled trial. JAMA 2001;286:322-326.

22. Narbutytė I, Narbutytė A, Linkevičienė L. Relationship between breastfeeding, bottle-feeding and development of malocclusion. Stomatologija 2013;15:67-72.

23 Jaafar SH, Jahanfar S, Angolkar M, Ho JJ. Effect of restricted pacifier use in breastfeeding term infants for increasing duration of breastfeeding. Cochrane Database Syst Rev 2012;7:CD007202.

24. WHO World Health Organization. Exclusive breastfeeding for six months best for babies everywhere. Available from: http://www.who. int/mediacentre/news/statements/2011/breastfeeding_20110115/en/ http://www.who.int/en/ [Latest access: March 2014].

25. Kramer MS, Kakuma R. Optimal duration of exclusive breastfeeding. Cochrane Database Syst Rev 2012;8:CD003517.

Received March 5, 2014 Accepted August 4, 2014 